\title{
Dietary requirements of synthesizable amino acids by animals: a paradigm shift in protein nutrition
}

Guoyao Wu

\begin{abstract}
Amino acids are building blocks for proteins in all animals. Based on growth or nitrogen balance, amino acids were traditionally classified as nutritionally essential or nonessential for mammals, birds and fish. It was assumed that all the "nutritionally nonessential amino acids (NEAA)" were synthesized sufficiently in the body to meet the needs for maximal growth and optimal health. However, careful analysis of the scientific literature reveals that over the past century there has not been compelling experimental evidence to support this assumption. NEAA (e.g., glutamine, glutamate, proline, glycine and arginine) play important roles in regulating gene expression, cell signaling, antioxidative responses, fertility, neurotransmission, and immunity. Additionally, glutamate, glutamine and aspartate are major metabolic fuels for the small intestine to maintain its digestive function and to protect the integrity of the intestinal mucosa. Thus, diets for animals must contain all NEAA to optimize their survival, growth, development, reproduction, and health. Furthermore, NEAA should be taken into consideration in revising the "ideal protein" concept that is currently used to formulate swine and poultry diets. Adequate provision of all amino acids (including NEAA) in diets enhances the efficiency of animal production. In this regard, amino acids should not be classified as nutritionally essential or nonessential in animal or human nutrition. The new Texas A\&M University's optimal ratios of dietary amino acids for swine and chickens are expected to beneficially reduce dietary protein content and improve the efficiency of their nutrient utilization, growth, and production performance.
\end{abstract}

Keywords: Diet, Metabolism, Nutrition, Protein, Requirements

\section{Introduction}

Amino acids (AA) are building blocks for proteins and must be present in cells for synthesis of polypeptides [1]. The carbon skeletons of eleven of these AA (namely cysteine, histidine, isoleucine, leucine, lysine, methionine, phenylalanine, threonine, tryptophan, tyrosine, and valine) are not synthesized from non-AA molecules in cells of any animals [2]. Therefore, they are classified as nutritionally essential AA (EAA) and must be included in diets for nonruminants to maintain physiological functions of cells, tissues, and the whole body [3,4]. This assumes particular importance for the small intestine because its basal membrane lacks an ability to take up a nutritionally significant quantity of all AA, except for glutamine, from the arterial circulation $[5,6]$.

Classical animal nutrition textbooks do not consider cysteine or tyrosine as an EAA [7-10], because they can

Correspondence: g-wu@tamu.edu

Department of Animal Science, Texas A\&M University, College Station, Texas 77843, USA

be synthesized from methionine and phenylalanine in the liver, respectively. However, the inability of all animals to form the carbon skeletons for methionine and phenylalanine means that there is no de novo synthesis of cysteine or tyrosine [2]. Also, intestinal mucosal cells must depend on cysteine and tyrosine as essential precursors to synthesize polypeptides [6]. Moreover, sulfur-containing or aromatic AA in arterial blood are largely not available to enterocytes (absorptive columnar cells in the small intestine). Thus, the presence of cysteine and tyrosine in diets, which can reduce the dietary needs of their precursor AA, are necessary to maintain the normal structure and function of the intestine $[5,6]$.

Rose did consider dietary needs of some of the traditionally classified NEAA in his human studies in the 1940s and 1950s, and reported that the omission of NEAA from the diet did not affect nitrogen balance in healthy adults during an eight-day experimental period [8]. Thus, it has 
long been assumed that all of the "nutritionally nonessential amino acids (NEAA)" are synthesized sufficiently in the body to meet the needs for maximal growth and optimal health [7-10]. However, careful analysis of the scientific literature reveals that over the past century there has not been compelling experimental evidence to support this assumption [2]. Indeed, in the 1960s and 1970s, A.E. Harper and other investigators found that the absence of NEAA from chicken and rat diets could not support maximal growth of these animals [11-15]. Growing evidence shows that nearly all of these synthesizable AA are inadequately present in typical plant protein (e.g., corn- and soybean meal)-based diets for growing swine relative to optimal whole-body protein synthesis [16]. Results of recent research revealed that the NEAA have important regulatory roles in nutrient metabolism to favor lean tissue growth and reduction of white adipose tissue [17-20]. Clearly, animals have dietary requirements for not only EAA, but also NEAA to achieve maximum growth and production performance [21-23]. This new concept has resulted in a paradigm shift in our understanding of protein nutrition and is highlighted in the present review article.

\section{Definitions of requirements of dietary $A A$}

Requirements of dietary AA can be classified as qualitative and quantitative [2]. Qualitative requirements are related to the question of "what AA are required for maintenance, optimum performance (e.g., growth, lactation, reproduction, and sports competition), and optimum health (e.g., prevention of chronic metabolic disorders, resistance to infectious disease, and recovery from illness)?" Quantitative requirements refer to the question of "how much of an AA is required for maintenance, optimum growth, and optimum health?" Feeding experiments have traditionally been employed to determine both qualitative and quantitative requirements of dietary AA by animals [24]. Minimal requirements of AA can also be estimated using so-called factorial analysis, that is, measurements of the loss of $\mathrm{N}$ by animals fed a nitrogen- or AA-free diet via urine, feces, gas, and other routes (maintenance) + AA deposited in animals + AA excreted as animal products (e.g., milk, egg, wool, and fetus) [2]. Over the past three decades, studies involving radioactive and stable AA tracers have been used along with the $\mathrm{N}$ balance technique to determine dietary requirements for EAA by humans and farm animals $[25,26]$. The more modern methods involve the use of direct and indirect indicators of AA oxidation during a period of several hours [26]. For yet unknown reasons, the AA oxidation methods generally yielded much higher values of dietary EAA requirements by humans than the nitrogen-balance studies. Readers are referred to recent articles [2,3,24] for insight into historical developments of dietary AA requirements. At present, little is known about dietary requirements for NEAA by mammals, birds, or fishes.

\section{Development of the ideal protein concept in animal nutrition \\ Chickens}

Beginning in the late 1950s, Mitchell and Scott at the University of Illinois conceptualized an ideal protein (optimal proportions and amounts of EAA) for diets of chickens $[27,28]$. NEAA were not considered by these authors. Early attempts to define an ideal protein were based on the EAA composition of eggs and casein, but were largely unsuccessful because of the excess of many EAA. In 1960, Scott's group simulated the profile of EAA in the chick carcass [29] to design a revised pattern of dietary EAA in an ideal protein for improving growth performance of chicks [30]. An improvement in the ideal protein was indeed achieved using this approach, but remained unsatisfactory due to the lack of NEAA in the diet. However, data on the composition of all EAA or NEAA in chicks were not available [29]. Subsequently, a mixture of several AA (cystine, glycine, proline and glutamate), which are synthesized from pre-existing AA (including EAA) by birds and had previously been thought to be NEAA in chicken nutrition, was used in dietary formulations to yield better results on growth performance [31,32]. This extensive research during the 1960 s and the 1970s culminated in several versions of the "chick AA requirement standard" for the first three weeks post-hatching [33-36]. Reference values were given in the Dean and Scott Standard [33], the Huston and Scott Reference Standard [34], the modified Sasse and Baker Reference Standard [35], and the Baker and Han's Ideal Chick Protein [36] (Table 1). The common features shared by these different recommended standards of dietary AA requirements by chickens are that the diets included: (a) all EAA that are not synthesized by chickens; (b) several AA (cystine, glutamate, glycine, proline, and tyrosine) that are synthesized from either EAA or $\alpha$-ketoglutarate plus ammonia by animals to various extents; and (c) no data on alanine, aspartate, asparagine, glutamine, or serine. Note that the patterns of AA composition in the ideal protein for chicks, as proposed by the Scott $[33,34]$ and Baker $[25,36]$, differ substantially for glycine and proline, and, to a lesser extent, for branched-chain AA, histidine, and sulfur-containing AA. These differences may reflect variations in AA composition of chickens reported in the literature. Because the content of proline plus hydroxyproline in the body of chickens was not known at that time, the relatively small amount of proline in the recommended ideal protein was only arbitrarily set and could limit responses of the animals to dietary EAA in their maximal growth and production performance. In contrast, very large amounts of glutamate (e.g., 13 times the lysine value in the modified Sasse and Baker Reference Standard) [35] were used to presumably provide for the entire need for "nonspecific AA N". However, key questions regarding whether glutamate fulfilled this role and whether 
Table 1 The University of Illinois patterns of amino acid compositions in ideal proteins for chicks during the first three wk post-hatching ${ }^{1}$

\begin{tabular}{|c|c|c|c|c|c|c|c|c|c|}
\hline \multirow[t]{2}{*}{ Amino acid } & \multirow[t]{2}{*}{$\begin{array}{l}\text { Amino acid content } \\
\text { in the carcass Ref. [29] } \\
\text { (\% of crude protein) })^{2}\end{array}$} & \multicolumn{2}{|c|}{$\begin{array}{l}\text { Dean \& Scott } \\
\text { standard (1965) } \\
\text { Ref. [33] }\end{array}$} & \multicolumn{2}{|c|}{$\begin{array}{l}\text { Huston \& Scott } \\
\text { standard (1968) } \\
\text { Ref. [34] }\end{array}$} & \multicolumn{2}{|c|}{$\begin{array}{l}\text { Sasse \& Baker } \\
\text { standard (1973) } \\
\text { Ref. [35] }\end{array}$} & \multicolumn{2}{|c|}{$\begin{array}{l}\text { Baker \& Han } \\
\text { standard (1994) } \\
\text { Ref. [36] }\end{array}$} \\
\hline & & $\begin{array}{l}\text { Amount } \\
\text { in diet }^{3}\end{array}$ & $\begin{array}{l}\% \text { of } \\
\text { lysine }\end{array}$ & $\begin{array}{l}\text { Amount } \\
\text { in diet }^{3}\end{array}$ & $\begin{array}{l}\% \text { of } \\
\text { lysine }\end{array}$ & $\begin{array}{l}\text { Amount } \\
\text { in diet }^{3}\end{array}$ & $\begin{array}{l}\% \text { of } \\
\text { lysine }\end{array}$ & $\begin{array}{l}\text { Amount } \\
\text { in diet }^{3}\end{array}$ & $\begin{array}{l}\% \text { of } \\
\text { lysine }\end{array}$ \\
\hline Arginine & 6.65 & 1.10 & 98.2 & 1.00 & 105 & 0.95 & 104 & 0.95 & 106 \\
\hline Cystine & - & 0.35 & 31.3 & 0.35 & 36.8 & 0.35 & 38.5 & 0.325 & 36.1 \\
\hline Glycine & - & 1.60 & 143 & 1.20 & 126 & 0.60 & 65.9 & 0.60 & 66.7 \\
\hline Isoleucine & 4.35 & 0.80 & 71.4 & 0.60 & 63.2 & 0.60 & 65.9 & 0.60 & 66.7 \\
\hline Histidine & 1.80 & 0.30 & 26.8 & 0.30 & 31.6 & 0.33 & 36.3 & 0.32 & 35.6 \\
\hline Leucine & 7.2 & 1.20 & 107 & 1.20 & 126 & 1.00 & 110 & 0.98 & 109 \\
\hline Lysine & 6.6 & 1.12 & 100 & 0.95 & 100 & 0.91 & 100 & 0.90 & 100 \\
\hline Methionine & $1.98^{\dagger}$ & 0.55 & 49.1 & 0.35 & 36.8 & 0.35 & 38.5 & 0.325 & 36.1 \\
\hline Phenylalanine & 4.25 & 0.68 & 60.7 & 0.50 & 52.6 & 0.50 & 55.0 & 0.50 & 55.6 \\
\hline Proline & - & 1.00 & 89.3 & 0.20 & 21.1 & 0.40 & 44.0 & 0.40 & 44.4 \\
\hline Threonine & 4.4 & 0.65 & 58.0 & 0.65 & 68.4 & 0.65 & 71.4 & 0.60 & 66.7 \\
\hline Tryptophan & 0.98 & 0.23 & 20.5 & 0.15 & 15.8 & 0.15 & 16.5 & 0.145 & 16.1 \\
\hline Tyrosine & - & 0.63 & 56.3 & 0.45 & 47.4 & 0.45 & 49.5 & 0.45 & 50.0 \\
\hline Valine & 5.0 & 0.82 & 73.2 & 0.82 & 86.3 & 0.69 & 75.8 & 0.69 & 76.7 \\
\hline Glutamic acid ${ }^{4}$ & - & 12.0 & 1071 & 10.0 & 1053 & 12.0 & 1319 & 12.0 & 1333 \\
\hline Total amino acids & & 23.0 & & 18.7 & & 19.9 & & 19.8 & \\
\hline Total nitrogen & & 2.83 & & 2.33 & & 2.37 & & 2.35 & \\
\hline
\end{tabular}

These ideal protein models were developed for 0 - to 21 - $d$-old broilers using crystalline amino acids. It was assumed that all of these amino acids were $100 \%$ available for absorption into enterocytes in chicks. Except for glycine and methionine, all amino acids are L-isomers. DL-methionine is used herein.

${ }^{2}$ Average values for 1 -wk-old and 4- to 5-wk-old chicks.

${ }^{3} \%$ of diet (as-fed basis; $90 \%$ dry matter).

${ }^{4}$ Provided as the nitrogenous source for synthesis of NEAA in chicks.

${ }^{\dagger}$ This value refers to L-methionine.

excess glutamate might interfere with the transport, metabolism and utilization of other AA in chickens were not addressed by the Illinois investigators [33-36]. Possibly due to these concerns and the publication of the NRC nutrient requirements for poultry in 1994 [37], Baker [38] did not include glutamate, glycine or proline in an ideal protein for diets of 0 - to 56-d-old chickens in his modified University of Illinois Ideal Ratios of Amino Acids for broiler chickens in 1997 (Table 2).

\section{Swine}

Work on the ideal protein for poultry diets laid a foundation for subsequent studies with growing pigs. Thus, the British nutritionist Cole suggested in 1980 that swine diets could be formulated to contain ideal ratios of EAA (with lysine as the reference AA) based on their concentrations in the pig carcass (almost exclusively tissue proteins) [39]. This idea was adopted first by the British Agricultural Research Council (ARC) in 1981 [40] and then by the U.S. National Research Council (NRC) in 1988 [41]. Unfortunately, histidine, arginine, and all synthesizable AA were not included in the ARC's concept of ideal protein (Table 3). Also, its conceptual foundation based solely on the EAA composition of the body was flawed, because the pattern of AA in the diet does not reflect the composition of AA in the animal $[16,42]$. This mismatch can be explained as follows: (a) individual AA in the diet undergo extensive catabolism and transformations at different rates in the small intestine; (b) the concentrations of AA in the circulation differ markedly from the relative abundance of AA in the diet; (c) individual AA in plasma have different metabolic fates in different animal tissues; and (d) the abundance of AA in tissue proteins differs greatly from that in the diet $[2,16,43]$. These major shortcomings limit the usefulness of the early versions of the ideal protein in formulating swine diets for maximal growth or production performance of pigs.

Dietary AA are required by animals primarily for maintenance (including the synthesis of nonprotein metabolites) and protein accretion [2]. However, the ARC's ideal protein concept did not take into consideration the relative contribution of maintenance to the total AA needs of the pig [40]. This was due, in part, to technical challenges to accurately determine maintenance requirements of AA, 
Table 2 The modified Baker and NRC patterns of changes in amino acid compositions in ideal proteins for 0 - to 56-d-old chicks (\% of lysine in diet)

\begin{tabular}{|c|c|c|c|c|}
\hline \multirow[t]{2}{*}{ Amino acid } & \multicolumn{3}{|c|}{ Baker's modified models (1997) for chicks [38] ${ }^{1}$} & \multirow{2}{*}{$\begin{array}{l}\text { NRC }(1994)[37] \\
\text { (0- to } 21-d \text {-old chicks) }\end{array}$} \\
\hline & 0 to $21 d^{2}$ & 21 to $42 d^{3}$ & 42 to $56 d^{4}$ & \\
\hline Lysine & 100 & 100 & 100 & 100 \\
\hline Methionine & 36 & 37 & 37 & 42 \\
\hline Cystine & 36 & 38 & 38 & 33 \\
\hline Threonine & 67 & 70 & 70 & 67 \\
\hline Valine & 77 & 80 & 80 & 75 \\
\hline Arginine & 105 & 108 & 108 & 104 \\
\hline Tryptophan & 16 & 17 & 17 & 17 \\
\hline Isoleucine & 67 & 69 & 69 & 67 \\
\hline Leucine & 109 & 109 & 109 & 100 \\
\hline Histidine & 35 & 35 & 35 & 29 \\
\hline Phe + Tyr & 105 & 105 & 105 & 112 \\
\hline
\end{tabular}

${ }^{1}$ These ratios are based on true digestible levels of amino acids in diet (as-fed basis; $90 \%$ dry matter). Adapted from Baker [38]. Except for glycine, all amino acids are L-isomers. ${ }^{2}$ Patterns of amino acid composition in the ideal protein are the same for male and female chickens. The amounts of digestible lysine in diet (as-fed basis; $90 \%$ dry matter) are $1.12 \%$ and $1.02 \%$ for male and female chickens, respectively.

${ }^{3}$ Patterns of amino acid composition in the ideal protein are the same for male and female chickens. The amounts of digestible lysine in diet (as-fed basis; $90 \%$ dry matter) are $0.89 \%$ and $0.84 \%$ for male and female chickens, respectively.

${ }^{4}$ Patterns of amino acid composition in the ideal protein are the same for male and female chickens. The amounts of digestible lysine in diet (as-fed basis; $90 \%$ dry matter) are $0.76 \%$ and $0.73 \%$ for male and female chickens, respectively.

${ }^{5}$ These ratios are based on total amino acids in a typical corn- and soybean meal-based diet. The amount of digestible lysine in diet (as-fed basis; $90 \%$ dry matter) is $1.2 \%$ for 0 - to 21 -d-old chicks.

Table 3 Previously proposed amino acid compositions for ideal proteins for $10-20 \mathbf{~ k g ~ g r o w i n g ~ p i g s ~}^{1}$ (\% of lysine)

\begin{tabular}{|c|c|c|c|c|c|c|}
\hline Amino acid & $\begin{array}{l}\text { Amino acid content } \\
\text { in the carcass }{ }^{2}\end{array}$ & $\begin{array}{l}\text { ARC (1981) } \\
\text { Ref. }[39]^{3}\end{array}$ & $\begin{array}{c}\text { Wang-Fuller (1989) } \\
\text { Ref. [44] }{ }^{4, a}\end{array}$ & $\begin{array}{c}\text { Chung-Baker (1992) } \\
\text { Ref. }[45]^{4, b}\end{array}$ & $\begin{array}{l}\text { NRC }(1998) \\
\text { Ref. }[40]^{5, b}\end{array}$ & $\begin{array}{l}\text { Baker }(2000) \\
\text { Ref. }[46]^{4, b}\end{array}$ \\
\hline Arginine & 91 & - & - & 42 & 42 & 42 \\
\hline Glycine & - & - & - & 100 & - & - \\
\hline Histidine & 47 & 33 & - & 32 & 32 & 32 \\
\hline Isoleucine & 53 & 55 & 60 & 60 & 54 & 60 \\
\hline Leucine & 111 & 100 & 110 & 100 & 102 & 100 \\
\hline Lysine & 100 & 100 & 100 & 100 & 100 & 100 \\
\hline Met + Cys & 49 & 50 & 63 & $60^{c}$ & $57^{e}$ & $60^{c}$ \\
\hline Phe + Tyr & 100 & 96 & 120 & $95^{d}$ & $94^{f}$ & $95^{d}$ \\
\hline Proline & - & - & - & 33 & - & - \\
\hline Tryptophan & 12 & 15 & 18 & 18 & 19 & 17 \\
\hline Threonine & 61 & 60 & 72 & 65 & 62 & 65 \\
\hline Valine & 72 & 70 & 75 & 68 & 68 & 68 \\
\hline Glutamate $^{6}$ & - & - & 826 & 878 & - & - \\
\hline
\end{tabular}

${ }^{1}$ These ratios are based on true digestible levels of amino acids in diets [40,44-46], except for ARC (1981) [36]. Except for glycine, all amino acids are L-isomers.

${ }^{2}$ Taken from Baker (1997) [38]. The body proteins in 20-45 kg pigs contain $63 \mathrm{~g}$ lysine/16 $\mathrm{g}$ nitrogen [38].

${ }^{3}$ These ratios are based on total amino acids in the diet. The total level of lysine in the diet is $1.10 \%$ (as-fed basis; $90 \%$ dry matter).

${ }^{4}$ The diet contains $1.20 \%$ true digestible lysine (as-fed basis; $90 \%$ dry matter).

${ }^{5}$ The diet contains $1.01 \%$ true digestible lysine (as-fed basis; $90 \%$ dry matter).

${ }^{6}$ Provided as the nitrogenous source for synthesis of other NEAA in animals.

${ }^{a}$ Dietary requirements are for $25-50 \mathrm{~kg}$ gilts.

${ }^{\mathrm{b}}$ Dietary requirements are for $10-20 \mathrm{~kg}$ pigs.

'The ratio of L-methionine to L-cystine is 1:1.

${ }^{d}$ The ratio of $L$-phenylalanine to $L$-tyrosine is $53: 47$.

${ }^{\mathrm{e}}$ The ratio of L-methionine to L-cystine is 47:53.

${ }^{f}$ The ratio of $L$-phenylalanine to L-tyrosine is $64: 36$. 
which include replacement of degraded proteins, as well as the use of AA for synthesis of low-molecular-weight substances and ATP production [1]. Between 1989 and 1990 , in attempts to improve the original ideal protein concept [39,40], T.C. Wang and M.F. Fuller [45] used gilts in the weight range of 25 to $50 \mathrm{~kg}$ to estimate an ideal pattern of dietary AA that included requirements for both maintenance and tissue protein accretion. However, these two authors also failed to consider arginine, histidine or all so-called NEAA in the ideal protein although they used glutamate at $826 \%$ of the lysine value to provide nonspecific AA-nitrogen [45]. As for the studies with chickens in the 1960s and 1970s, there were also concerns over the assumptions for inclusion of this high level of glutamate in the swine diet that lacks all other NEAA. While glutamate was used to prepare isonitrogenous diets in the previous studies, none of these investigators considered that animals have a dietary requirement of glutamate for optimal growth and production performance.
Having recognized the need to modify the ideal protein concept for formulating swine diets, D.H. Baker took great efforts between 1990 and 2000 to evaluate dietary requirements of EAA by $10-20 \mathrm{~kg}$ swine. In their original study, D.H. Baker and his student T.K. Chung added arginine ( $42 \%$ of lysine), glycine ( $100 \%$ of lysine), histidine (32\% of lysine), and proline (33\% of lysine) to the basal diet containing $1.2 \%$ true digestible lysine and using glutamate at $878 \%$ of the lysine value to provide nonspecific AA-nitrogen [46]. However, other synthesizable AA (including alanine, aspartate, asparagine, cysteine, glutamine, serine, and tyrosine) were not considered in the revised version of the ideal protein and the rationale for the use of arginine, glycine, histidine, and proline at different proportions to lysine was not explained [46]. Furthermore, the bases for other assumptions were unknown, including: (a) whether glutamate is an effective precursor for sufficient synthesis of all other AA (including aspartate, glutamine, and serine) in specific tissues (e.g., the small intestine, spleen, and lymph nodes) and

Table 4 Compositions of amino acids in the whole-body proteins of chicks and pigs

\begin{tabular}{|c|c|c|c|c|c|c|c|c|}
\hline \multirow[t]{2}{*}{ Amino acid } & \multicolumn{2}{|c|}{ Chicks $^{1}$} & \multicolumn{2}{|l|}{ Pigs $^{2}$} & \multirow{2}{*}{ Corn grain ${ }^{3}$} & \multirow{2}{*}{\multicolumn{2}{|c|}{$\begin{array}{c}{\text { Soybean } \text { meal }^{4}}^{\text {Sorghum grain }}{ }^{5} \\
\text { g AA/100 g foodstuff }\end{array}$}} & \multirow[t]{2}{*}{ Meat $\&$ bone meal ${ }^{6}$} \\
\hline & mg AA/g protein & $\%$ of lysine & mg AA/g protein & $\%$ of lysine & & & & \\
\hline Alanine & 66.3 & 108 & 65.7 & 109 & 0.71 & 1.95 & 0.96 & 4.78 \\
\hline Arginine & 68.5 & 111 & 67.7 & 112 & 0.38 & 3.18 & 0.41 & 3.67 \\
\hline Asparagine & 36.5 & 59.3 & 36.0 & 59.7 & 0.35 & 2.10 & 0.31 & 2.21 \\
\hline Aspartate & 43.1 & 70.1 & 42.8 & 71.0 & 0.43 & 3.14 & 0.36 & 3.08 \\
\hline Cysteine & 15.0 & 24.4 & 13.2 & 21.9 & 0.20 & 0.70 & 0.19 & 0.49 \\
\hline Glutamine & 50.5 & 82.1 & 51.2 & 84.9 & 1.02 & 3.80 & 0.85 & 2.81 \\
\hline Glutamate & 82.9 & 135 & 84.6 & 140 & 0.64 & 4.17 & 1.18 & 4.05 \\
\hline Glycine & 115 & 187 & 117 & 19.4 & 0.40 & 2.30 & 0.39 & 8.67 \\
\hline Histidine & 21.1 & 34.3 & 20.8 & 34.5 & 0.23 & 1.13 & 0.23 & 1.19 \\
\hline Isoleucine & 35.9 & 58.4 & 35.3 & 58.5 & 0.34 & 2.03 & 0.38 & 1.92 \\
\hline Leucine & 69.2 & 113 & 68.3 & 113 & 1.13 & 3.44 & 1.21 & 3.56 \\
\hline Lysine & 61.5 & 100 & 60.3 & 100 & 0.25 & 2.80 & 0.21 & 3.13 \\
\hline Methionine & 18.9 & 30.7 & 18.7 & 31.0 & 0.21 & 0.60 & 0.20 & 1.10 \\
\hline Phenylalanine & 34.8 & 56.6 & 34.3 & 56.9 & 0.46 & 2.21 & 0.51 & 1.85 \\
\hline Proline & 85.3 & 139 & 86.1 & 143 & 1.06 & 2.40 & 0.96 & 5.86 \\
\hline OH-Proline & 34.8 & 56.6 & 37.9 & 62.9 & 0.00 & 0.09 & 0.00 & 2.88 \\
\hline Serine & 45.0 & 73.2 & 44.3 & 73.5 & 0.45 & 2.12 & 0.46 & 2.08 \\
\hline Threonine & 36.3 & 59.0 & 35.1 & 58.2 & 0.31 & 1.76 & 0.32 & 2.42 \\
\hline Tryptophan & 11.6 & 18.9 & 11.1 & 18.4 & 0.07 & 0.62 & 0.10 & 0.39 \\
\hline Tyrosine & 26.6 & 43.3 & 27.2 & 45.1 & 0.43 & 1.66 & 0.45 & 1.45 \\
\hline Valine & 41.8 & 68.0 & 42.2 & 70.0 & 0.44 & 2.09 & 0.50 & 2.23 \\
\hline
\end{tabular}

Except for glycine, all amino acids are L-isomers. Adapted from Wu et al. [21]. Calculations were based on the molecular weights of intact amino acids. $\mathrm{OH}$-Pro = hydroxyproline.

${ }^{1}$ Chickens (10-d-old). The content of protein in the body is $14.3 \mathrm{~g} / 100 \mathrm{~g}$ wet tissue.

${ }^{2}$ Pigs (30-d-old). The content of protein in the body is $14.1 \mathrm{~g} / 100 \mathrm{~g}$ wet tissue.

${ }^{3} \mathrm{As}$-fed basis (89.0\% dry matter). Corn grain contains $9.3 \%$ crude protein (as-fed basis) [91].

${ }^{4}$ As-fed basis ( $89.0 \%$ dry matter). Soybean meal contains $43.6 \%$ crude protein (as-fed basis) [91].

${ }^{5}$ As-fed basis ( $89.1 \%$ dry matter). Sorghum grain contains $10.1 \%$ crude protein (as-fed basis) [91].

${ }^{6}$ As-fed basis (96.1\% dry matter). Meat \& Bone meal contains $52.0 \%$ crude protein (as-fed basis) [91]. 
the whole body; or (b) whether the high content of glutamate in the diet may affect the transport, metabolism and utilization of other AA in the diet. Furthermore, little attention was paid to inter-organ fluxes of amino acids relative to their intracellular metabolism. For example, only $5 \%$ of dietary glutamate enters the portal circulation in growing pigs $[5,6]$. In addition, although intracellular glutamate is used to synthesize aspartate, many extra-intestinal tissues and cells (e.g., liver and red blood cells) have a limited ability to take up glutamate from the blood circulation [2]. The 10th edition of the NRC Swine Nutrient Requirements published in 1998 [41] did not recognize the needs of pigs for dietary proline or glycine; therefore, Baker [47] omitted glycine and proline from the last version of his "ideal protein" for swine diet formulations in 2000, as he did in 1997 [38]. Over the past two decades, there have been successful attempts to refine the patterns of some AA in diets for lactating, suckling, weanling, finishing, and gestating pigs by addition of arginine [48-53], glutamine [54-59], glutamate [60-64], proline [65-67], or glycine [68,69], or by determining mammary gland growth, changes of whole-body AA composition, and milk yields in lactating sows $[70,71]$. The outcomes are increases in neonatal and postweaning growth, lactation performance, and litter size in pigs.

Growing evidence shows that both EAA and NEAA (e.g. arginine, glutamine, glutamate, glycine, and proline) play important roles in regulating gene expression, cell

Table 5 True ideal digestibilities of amino acids in corn and soybean meals for poultry and swine diets (\%)

\begin{tabular}{|c|c|c|c|c|c|c|c|c|}
\hline \multirow[t]{2}{*}{ Amino acid } & \multicolumn{4}{|c|}{ Chicks $^{1}$} & \multicolumn{4}{|c|}{ Pigs $^{2}$} \\
\hline & Corn grain & Soybean meal & Sorghum grain & Meat \& Bone meal & Corn grain & Soybean meal & Sorghum grain & Meat \& bone meal \\
\hline Alanine & 87.6 & 88.9 & 85.4 & 90.2 & 88.5 & 89.0 & 87.2 & 90.5 \\
\hline Arginine & 88.4 & 90.6 & 87.2 & 91.4 & 89.3 & 90.2 & 88.4 & 91.3 \\
\hline Asparagine & 86.5 & 88.3 & 85.9 & 90.6 & 86.8 & 88.5 & 86.0 & 90.2 \\
\hline Aspartate & 87.2 & 89.5 & 86.1 & 90.2 & 86.3 & 88.2 & 85.8 & 89.7 \\
\hline Cysteine & 85.1 & 86.4 & 84.8 & 89.4 & 86.0 & 87.1 & 85.1 & 89.0 \\
\hline Glutamine & 88.6 & 89.5 & 87.6 & 90.8 & 87.7 & 89.2 & 86.8 & 90.8 \\
\hline Glutamate & 89.2 & 90.2 & 88.4 & 91.2 & 88.1 & 89.6 & 87.4 & 91.0 \\
\hline Glycine & 86.4 & 88.3 & 85.7 & 90.5 & 86.6 & 88.0 & 85.7 & 89.5 \\
\hline Histidine & 85.5 & 87.4 & 84.9 & 89.6 & 87.0 & 88.5 & 86.2 & 90.2 \\
\hline Isoleucine & 88.7 & 89.3 & 88.0 & 90.8 & 88.2 & 88.9 & 87.6 & 90.5 \\
\hline Leucine & 88.2 & 89.0 & 87.6 & 90.3 & 87.8 & 89.6 & 86.4 & 90.6 \\
\hline Lysine & 85.0 & 88.4 & 84.3 & 90.0 & 84.5 & 89.8 & 83.7 & 90.4 \\
\hline Methionine & 87.5 & 90.1 & 86.8 & 90.6 & 88.6 & 89.1 & 87.4 & 90.5 \\
\hline Phenylalanine & 89.1 & 90.3 & 88.5 & 90.9 & 89.5 & 90.0 & 88.9 & 91.0 \\
\hline Proline & 86.8 & 88.0 & 85.9 & 89.4 & 86.4 & 87.2 & 86.0 & 89.2 \\
\hline Hydroxyproline & - & - & - & 88.7 & - & - & - & 88.4 \\
\hline Serine & 88.4 & 90.2 & 87.5 & 91.1 & 88.6 & 89.0 & 87.9 & 90.6 \\
\hline Threonine & 85.2 & 86.5 & 84.8 & 89.3 & 84.9 & 86.8 & 84.3 & 88.5 \\
\hline Tryptophan & 86.0 & 87.2 & 85.3 & 89.0 & 85.2 & 88.1 & 84.6 & 89.7 \\
\hline Tyrosine & 88.5 & 89.6 & 88.0 & 91.4 & 89.0 & 90.2 & 88.2 & 91.0 \\
\hline Valine & 88.2 & 89.8 & 87.6 & 90.7 & 87.1 & 88.7 & 86.1 & 90.3 \\
\hline
\end{tabular}

${ }^{1}$ Except for glycine, all amino acids are L-isomers. Broiler chickens (21-wk-old). Ileal digestae were obtained from 21-d-old broiler chicks [92] at $6 \mathrm{~h}$ after they were fed either a nitrogen-free purified diet (consisting of $94.9 \%$ cornstarch, $2 \%$ soybean oil, $1.65 \%$ dicalcium phosphate, $0.5 \%$ vitamin premix, $0.5 \%$ mineral premix, $0.25 \% \mathrm{NaCl}$, and $0.2 \%$ chromic oxide) or a diet containing the test feed ingredient (consisting of $79.9 \%$ cornstarch, $15 \%$ test ingredient, $2 \%$ soybean oil, $1.65 \%$ dicalcium phosphate, $0.5 \%$ vitamin premix, $0.5 \%$ mineral premix, $0.25 \% \mathrm{NaCl}$, and $0.2 \%$ chromic oxide) and then euthanized by cervical dislocation. The amount of the diet was provided to overnight ( $16 \mathrm{~h}$ )-fasted chicks at $25 \mathrm{~g} / \mathrm{kg}$ body weight. Amino acids in the diet, as well as the digestae from chicks fed either the nitrogen-free purified diet or the diet containing the test feed ingredient were analyzed as described by Li et al. [91,94] to calculate the true ideal digestibilities of AA [2]. Data are means for 8 chicks per ingredient, with pooled SEM values being less than $0.8 \%$.

${ }^{2}$ Pigs (50- to 65-d-old). lleal digestae were obtained from 50- to 65-d-old cannulated pigs [93] at $6 \mathrm{~h}$ after they were fed either a nitrogen-free purified diet (consisting of $94.9 \%$ cornstarch, $2 \%$ soybean oil, $1.65 \%$ dicalcium phosphate, $0.5 \%$ vitamin premix, $0.5 \%$ mineral premix, $0.25 \% \mathrm{NaCl}$, and $0.2 \%$ chromic oxide) or a diet containing the test feed ingredient (consisting of $79.9 \%$ cornstarch, $15 \%$ test ingredient, $2 \%$ soybean oil, $1.65 \%$ dicalcium phosphate, $0.5 \%$ vitamin premix, $0.5 \%$ mineral premix, $0.25 \%$ $\mathrm{NaCl}$, and $0.2 \%$ chromic oxide). The amount of the diet was provided to overnight ( $16 \mathrm{~h}$ )-fasted pigs at $12 \mathrm{~g} / \mathrm{kg}$ body weight. Amino acids in the diet, as well as the digestae from pigs fed either the nitrogen-free purified diet or the diet containing the test feed ingredient were analyzed as described by Li et al. [91,94] to calculate the true ideal digestibilities of AA [2]. Data are means for 6 pigs per ingredient, with pooled SEM values being less than $1.2 \%$. 
signaling, nutrient transport and metabolism, intestinal microbiota, anti-oxidative responses, and immune responses $[1,2]$. Based on these lines of compelling evidence from animal studies, $\mathrm{Wu}$ and colleagues proposed the new concept of functional AA, which are defined as those AA that participate in and regulate key metabolic pathways to improve health, survival, growth, development, lactation, and reproduction of the organisms [1,2,16]. Metabolic pathways include: (a) intracellular protein turnover (synthesis and degradation) and associated events; (b) AA synthesis and catabolism; (c) generation of small peptides, nitrogenous metabolites, and sulfur-containing substances (e.g., $\mathrm{H}_{2} \mathrm{~S}$ ); (d) urea cycle and uric acid synthesis; (e) lipid and glucose metabolism; (f) one-carbon-unit metabolism and DNA synthesis; and (g) cellular redox signaling. Functional AA can be nutritionally "essential", "nonessential", or conditionally essential AA. Notably, the concept of functional AA in nutrition has also been adopted for fish [72-74], poultry [75-79], and small laboratory animals (e. g., mice and rats) [80-83]. Readers are referred to recent reviews and original research article on these new developments [24,84-101].

Texas A\&M University's optimal ratios of amino acids in diets for swine and chickens

The carbon skeletons of EAA (including tyrosine and cysteine) are not synthesized from non-AA substances in animals [2]. As noted previously, synthesis of NEAA from EAA in animals is inadequate for their maximal growth, milk production, and reproduction performance or for optimal development and health. Thus, the traditional classification of AA as EAA or NEAA is purely a matter of definition. For example, emerging evidence shows that arginine, glutamine, glutamate, and glycine play important roles in regulating gene expression, cell signaling, antioxidative responses, and immunity [51-56]. Additionally, glutamate, glutamine, and aspartate are major metabolic fuels for enterocytes [6] and also regulate intestinal and neurological development and function [2]. In addition, glutamine is essential for ATP production, synthesis of nucleotides,

Table 6 Texas A\&M University's optimal ratios of true digestible amino acids in diets for swine ${ }^{1}$ (\% of diet (as-fed basis))

\begin{tabular}{|c|c|c|c|c|c|c|c|}
\hline \multirow[t]{2}{*}{ Amino acid } & \multicolumn{4}{|c|}{ Growing pigs, $\mathbf{k g}^{2}$} & \multicolumn{2}{|c|}{ Gestating pigs ${ }^{3}$} & \multirow[t]{2}{*}{ Lactating sows $^{2}$} \\
\hline & $5-10$ & $10-20$ & $20-50$ & $50-110$ & d 0-90 & d 90-114 & \\
\hline Alanine & 1.14 & 0.97 & 0.80 & 0.64 & 0.69 & 0.69 & 0.83 \\
\hline Arginine & 1.19 & 1.01 & 0.83 & 0.66 & 1.03 & 1.03 & 1.37 \\
\hline Asparagine & 0.80 & 0.68 & 0.56 & 0.45 & 0.50 & 0.50 & 0.66 \\
\hline Aspartate & 1.14 & 0.97 & 0.80 & 0.64 & 0.61 & 0.61 & 0.94 \\
\hline Cysteine & 0.32 & 0.28 & 0.24 & 0.20 & 0.19 & 0.19 & 0.26 \\
\hline Glutamate & 2.00 & 1.70 & 1.39 & 1.12 & 0.89 & 0.89 & 1.81 \\
\hline Glutamine & 1.80 & 1.53 & 1.25 & 1.00 & 1.00 & 1.60 & 1.38 \\
\hline Glycine & 1.27 & 1.08 & 0.89 & 0.71 & 0.48 & 0.48 & 0.75 \\
\hline Histidine & 0.46 & 0.39 & 0.32 & 0.26 & 0.29 & 0.29 & 0.39 \\
\hline Isoleucine & 0.78 & 0.66 & 0.54 & 0.43 & 0.45 & 0.45 & 0.66 \\
\hline Leucine & 1.57 & 1.33 & 1.09 & 0.87 & 1.03 & 1.03 & 1.41 \\
\hline Lysine & 1.19 & 1.01 & 0.83 & 0.66 & 0.51 & 0.51 & 0.80 \\
\hline Methionine & 0.32 & 0.28 & 0.24 & 0.20 & 0.16 & 0.16 & 0.25 \\
\hline Phenylalanine & 0.86 & 0.73 & 0.60 & 0.48 & 0.54 & 0.54 & 0.77 \\
\hline Proline & 1.36 & 1.16 & 0.95 & 0.76 & 0.89 & 0.89 & 1.24 \\
\hline Serine & 0.70 & 0.60 & 0.49 & 0.39 & 0.45 & 0.45 & 0.74 \\
\hline Threonine & 0.74 & 0.65 & 0.55 & 0.46 & 0.41 & 0.41 & 0.56 \\
\hline Tryptophan & 0.22 & 0.19 & 0.17 & 0.14 & 0.11 & 0.11 & 0.18 \\
\hline Tyrosine & 0.67 & 0.57 & 0.46 & 0.37 & 0.40 & 0.40 & 0.62 \\
\hline Valine & 0.85 & 0.72 & 0.59 & 0.47 & 0.55 & 0.55 & 0.72 \\
\hline
\end{tabular}

'Data are taken from Wu [95]. Except for glycine, all amino acids are L-isomers. Values are based on true ileal digestible amino acids. Crystalline amino acids (e.g., feed-grade arginine, glutamate, glutamine and glycine), whose true ileal digestibility is $100 \%$, can be added to a diet to obtain their optimal ratios. The molecular weights of intact amino acids were used for all the calculations. The content of dry matter in all the diets was $90 \%$. The content of metabolizable energy in the diets of growing pigs, gestating pigs, and lactating pigs is 3,330, 3,122, and 3,310 Kcal/kg diet, respectively.

${ }^{2}$ Fed ad libitum (90\% dry matter).

${ }^{3}$ Fed $2 \mathrm{~kg} / \mathrm{d}$ on d $0-90$, and $2.3 \mathrm{~kg} / \mathrm{d}$ on d $90-114$ (90\% dry matter). 
expression of anti-oxidative genes, and redox signaling in enterocytes [57]. Furthermore, glutamate activates chemical sensing in the gastrointestinal tract and may inhibit degradation of both EAA and NEAA by intestinal microbes $[2,60]$. Finally, proline and arginine, which are major sources of ornithine for intestinal and placental synthesis of polyamines [42], are essential for DNA and protein synthesis and also participate in protein and DNA methylation, and, thus genetic and epigenetic regulation of cell growth and development [2]. Collectively, animals have dietary requirements for all synthesizable AA to achieve their full genetic potential for growth, development, reproduction, lactation, and resistance to infectious disease [21].

Composition of EAA in feed ingredients and true ileal digestibilities of EAA in swine [41] and poultry [37,90] have been published. As an initial step to define NEAA requirements by animals, we recently determined the composition of all protein-AA in major feedstuffs [86] and in animal tissues [21]. Examples are given in Table 4 for corn grain, soybean meal, sorghum grain, and meat \& bone meal. Based on the previous studies of AA biochemistry and nutrition (including AA metabolism and tissue protein gains) in poultry e.g., 3, [37] and swine e.g., [48-69], the author of the present work would like to propose Texas A\&M University's optimal ratios of true digestible AA in diets for swine (Table 5) and chickens (Table 6) during different phases of growth and production. The values for 5 - to $10-\mathrm{kg}$ young pigs are based primarily on consideration of: (a) the entry of dietary AA into the portal vein for 30-day-old postweaning pigs, as compared to the accretion of AA in the body [16]; (b) the published data of Baker [47] and NRC [41] on dietary EAA requirements; and (c) the estimated rates of AA synthesis, catabolism and accretion in the body $[2,16,88]$. Specifically, these estimations are that: (a) rates of net synthesis of aspartate, arginine, glutamate, glutamine, glycine, and proline in extraintestinal tissues of 5-10 kg postweaning pigs are 195, $361,415,1149,331$, and $276 \mathrm{mg} / \mathrm{kg}$ body weight per day, respectively; (b) rates of catabolism (including oxidation and synthesis of low-molecular-weight substances) of alanine and tyrosine in extra-intestinal tissues are $30 \%$ of their rates of accretion in body proteins; (c) rates of catabolism (including oxidation) of leucine and isoleucine in extra-intestinal tissues are $30 \%$ and $25 \%$ of their rates of accretion in body proteins, respectively; (d) the rate of catabolism (including oxidation) of asparagine in extraintestinal tissues is $124 \mathrm{mg} / \mathrm{kg}$ body weight per day; (e) rates of catabolism (including oxidation) of valine and serine in extra-intestinal tissues are $15 \%$ of their rates of accretion in body proteins; (f) the rate of catabolism (including oxidation) of phenylalanine in extra-intestinal tissues is $124 \mathrm{mg} / \mathrm{kg}$ body weight per day; and (g) the ratio of phenylalanine to tyrosine is 60:40, whereas the ratio of methionine to cysteine is 1:1. Additionally, the Texas
A\&M University's optimal ratios of true digestible AA in diets for gestating and lactating sows are based on previous studies of dietary AA composition [89], ileal true digestibility of AA in feed ingredients (Table 4 and Ref. [41]), composition of EAA and NEAA in the body (Table 4), embryonic/fetal survival and growth $[42,49,57]$, as well as milk production and piglet growth [42,50,57].

Several additional comments on the Texas A\&M University's optimal ratios of dietary AA are warranted. First, the author adopts the NRC [41] values for lysine, methionine, threonine, and tryptophan in the Texas A\&M University's model for 5- to 10-kg pigs. Second, optimal ratios of EAA in diets of older pigs are based on the suggestions of the NRC [41] and Baker [47] in that the ratios of

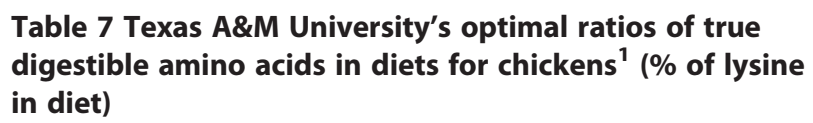

\begin{tabular}{|c|c|c|c|}
\hline \multirow[t]{2}{*}{ Amino acid } & \multicolumn{3}{|c|}{ Age of chickens } \\
\hline & 0 to $21 \mathrm{~d}^{2}$ & 21 to $42 d^{3}$ & 42 to $56 d^{4}$ \\
\hline Alanine & 102 & 102 & 102 \\
\hline Arginine & 105 & 108 & 108 \\
\hline Asparagine & 56 & 56 & 56 \\
\hline Aspartate & 66 & 66 & 66 \\
\hline Cysteine & 32 & 33 & 33 \\
\hline Glutamate & 178 & 178 & 178 \\
\hline Glutamine & 128 & 128 & 128 \\
\hline Glycine & 176 & 176 & 176 \\
\hline Histidine & 35 & 35 & 35 \\
\hline Isoleucine & 67 & 69 & 69 \\
\hline Leucine & 109 & 109 & 109 \\
\hline Lysine & 100 & 100 & 100 \\
\hline Methionine & 40 & 42 & 42 \\
\hline Phenylalanine & 60 & 60 & 60 \\
\hline Proline & 184 & 184 & 184 \\
\hline Serine & 69 & 69 & 69 \\
\hline Threonine & 67 & 70 & 70 \\
\hline Tryptophan & 16 & 17 & 17 \\
\hline Tyrosine & 45 & 45 & 45 \\
\hline Valine & 77 & 80 & 80 \\
\hline
\end{tabular}

${ }^{1}$ Except for glycine, all amino acids are L-isomers. Values are based on true ileal digestible amino acids.

${ }^{2}$ Patterns of amino acid composition in the ideal protein are the same for male and female chickens. The amounts of digestible lysine in diet (as-fed basis; $90 \%$ dry matter) are $1.12 \%$ and $1.02 \%$ for male and female chickens, respectively.

${ }^{3}$ Patterns of amino acid composition in the ideal protein are the same for male and female chickens. The amounts of digestible lysine in diets (as-fed basis; $90 \%$ dry matter) are $0.89 \%$ and $0.84 \%$ for male and female chickens, respectively.

${ }^{4}$ Patterns of amino acid composition in the ideal protein are the same for male and female chickens. The amounts of digestible lysine in diets (as-fed basis; $90 \%$ dry matter) are $0.76 \%$ and $0.73 \%$ for male and female chickens, respectively. 
tryptophan, sulfur-AA, and threonine to lysine (all based on true digestibility of EAA) increase slightly with age, whereas the ratios of other EAA to lysine are not altered substantially during postnatal development. Third, this is the first time that NEAA are included in optimal ratios of dietary AA for pigs and poultry at various physiological stages. Fourth, for EAA, the ratios of BCAA, histidine, phenylalanine or tyrosine to lysine in the Texas A\&M University's optimal ratios of dietary are higher than those proposed by the NRC [41] and Baker [47] for swine. This is based on the following considerations [2]: (a) BCAA are actively degraded in extra-hepatic and extra-intestinal tissues; (b) leucine can stimulate muscle protein synthesis in young pigs; (c) leucine, isoleucine and valine should be in an appropriate ratio to prevent AA imbalance; (d) large amounts of histidine-containing dipeptides are present in skeletal muscle; and (e) tyrosine is actively utilized in multiple metabolic pathways and its carbon skeleton is formed only from phenylalanine in animals. Finally, the data on dietary EAA requirements by chickens [38], along with composition of EAA and NEAA as well as AA accretion in the body ( 85 and Table 4) and new knowledge of AA metabolism in birds [2], provided the basis for the proposed Texas A\&M University's optimal ratios of amino acids in chicken diets (Table 7). The recommended values for EAA and NEAA requirements must be revised as new and compelling experimental data become available.

\section{Conclusion and perspectives}

Amino acids have versatile and important physiological functions beyond their roles as the building blocks of protein [101]. Thus, dietary NEAA and EAA are necessary for the survival, growth, development, reproduction and health of animals. Growing evidence shows that pigs and poultry cannot synthesize sufficient amounts of all NEAA to achieve their maximum genetic potential [95-100]. NEAA (e.g., glutamine, glutamate, proline, glycine and arginine) play important roles in regulating gene expression, cell signaling, antioxidative responses, neurotransmission, and immunity. Additionally, glutamate, glutamine and aspartate are major metabolic fuels for the small intestine to maintain its digestive function and to protect its mucosal integrity. While metabolic needs for an AA by animals do not necessarily translate into its dietary needs, results of recent studies indicate that animals have both metabolic and dietary needs for AA that are synthesized in the body [101-115]. Thus, "synthesizable amino acids" should not be considered as "nutritionally nonessential amino acids" in animal feeding. Besides EAA, NEAA and conditionally essential AA should all be taken into consideration in: (a) revising the classical "ideal protein" concept; and (b) formulating balanced diets to improve protein accretion, feed efficiency, and health in animals. The Texas A\&M University's optimal ratios of AA in diets for swine or poultry, as proposed herein, are based on experimental data from published biochemical and nutritional studies. This new initiative will provide a much-needed framework for both qualitative and quantitative analysis of dietary requirements for all AA by livestock, poultry and fish through conduct of additional research. Adoption of these recommended values in animal feeding are expected to beneficially reduce dietary protein content and improve the efficiency of nutrient utilization, growth, and production performance of farm animals. The concept of dietary requirements for NEAA also has important implications in human nutrition and health.

\section{Competing interests}

The author declares no competing interests.

\section{Authors' contributions}

The author wrote this paper and approved the final version of the manuscript.

\section{Acknowledgments}

The author thanks Dr. Fuller W. Bazer for helpful discussions and review of the manuscript, colleagues (particularly Drs. Fuller W. Bazer, Robert C. Burghardt, Yongqing Hou, Gregory A. Johnson, Sung Woo Kim, Darrell A. Knabe, Defa Li, Wilson G. Pond, Stephen B. Smith, Junjun Wang, Zhenlong $\mathrm{Wu}$, and Yulong Yin) for enjoyable collaborations on swine protein digestion and nutrition research, as well as graduate students, postdoctoral fellows, technicians, and visiting scholars for their important contributions to our research program. The author's work at Texas A\&M University was supported by National Research Initiative Competitive Grants from the Animal Reproduction Program (2008-35203-19120 and 2011-67015-20028) and Animal Growth \& Nutrient Utilization Program (2008-35206-18764, 2008-35206-18762, 2009-35206-05211, and 2014-67015-21770) of the USDA National Institute of Food and Agriculture, Texas A\&M AgriLife Research (H-8200), Ajinomoto Inc. (Tokyo, Japan), and Gentech Inc. (Shanghai, China). This paper is dedicated to the memory of Dr. Darrell A Knabe, a dear friend of the author, a wonderful human being, and a well-respected scientist.

\section{Received: 2 April 2014 Accepted: 8 June 2014}

Published: 14 June 2014

\section{References}

1. Wu G: Amino acids: metabolism, functions, and nutrition. Amino Acids 2009, 37:1-17.

2. Wu G: Amino Acids: Biochemistry and Nutrition. Boca Raton, Florida: CRC Press; 2013.

3. Baker $\mathrm{DH}$ : Advances in protein-amino acid nutrition of poultry. Amino Acids 2009, 37:29-41

4. Wu G: Recent advances in swine amino acid nutrition. J Anim Sci Biotechnol 2010, 1:49-61.

5. Stoll B, Burrin DG: Measuring splanchnic amino acid metabolism in vivo using stable isotopic tracers. J Anim Sci 2006, 84(Suppl):E60-E72.

6. Wu G: Intestinal mucosal amino acid catabolism. J Nutr 1998, 128:1249-1252.

7. Rose WC: The sequence of events leading to the establishment of the amino acid needs of man. Am J Public Health 1968, 58:2020-2027.

8. Morrison FB: Feeds and Feeding. 22nd edition. Ithaca, New York: The Morrison Publishing Company; 1956.

9. Maynard LA, Loosli JK, Hintz HF, Warner RG: Animal Nutrition. 7th edition. New York: McGraw-Hill Book Company; 1979.

10. Crampton EW, Harris LE: Applied Animal Nutrition. 2nd edition. San Francisco: W.H. Freeman and Company; 1969.

11. Rogers $\mathrm{QR}$, Chen DM, Harper AE: The importance of dispensable amino acids for maximal growth in the rat. Proc Soc Exp Biol Med 1970, 134:517-522.

12. Breuer LH Jr, Pond WG, Warner RG, Loosli JK: The role of dispensable amino acids in the nutrition of the rat. J Nutr 1964, 82:499-506.

13. Womack M: Amino acid feeding studies: effects of various nonessential nitrogen sources and of added water. Proc Soc Exp Biol Med 1969, 131:977-979. 
14. Stucki WP, Harper AE: Importance of dispensable amino acids for normal growth of chicks. J Nutr 1961, 74:377-383.

15. Maruyama K, Sunde ML, Harper AE: Is L-glutamic acid nutritionally a dispensable amino acid for the young chick? Poultry Sci 1976, 55:45-60.

16. Wu G, Bazer FW, Burghardt RC, Johnson GA, Kim SW, Knabe DA, Li XL, Satterfield MC, Smith SB, Spencer TE: Functional amino acids in swine nutrition and production. In Dynamics in Animal Nutrition. Edited by Doppenberg J, van der Aar P. The Netherlands: Wageningen Academic Publishers; 2010:69-98.

17. Dai ZL, Li XL, Xi PB, Zhang J, Wu G, Zhu WY: Regulatory role for L-arginine in the utilization of amino acids by pig small-intestinal bacteria. Amino Acids 2012, 43:233-244.

18. San Gabriel A, Uneyama $\mathrm{H}$ : Amino acid sensing in the gastrointestinal tract. Amino Acids 2013, 45:451-461.

19. Bauchart-Thevret C, Cui LW, Wu G, Burrin DG: Arginine-induced stimulation of protein synthesis and survival in IPEC-J2 cells is mediated by mTOR but not nitric oxide. Am J Physiol 2010, 299:E899-E909.

20. Wu ZL, Satterfield MC, Bazer FW, Wu G: Regulation of brown adipose tissue development and white fat reduction by L-arginine. Curr Opin Clin Nutr Metab Care 2012, 15:529-538.

21. Wu G, Wu ZL, Dai ZL, Yang Y, Wang WW, Liu C, Wang B, Wang JJ, Yin YL: Dietary requirements of "nutritionally nonessential amino acids" by animals and humans. Amino Acids 2013, 44:1107-1113.

22. Phang JM, Liu W, Hancock C: Bridging epigenetics and metabolism: Role of non-essential amino acids. Epigenetics 2013, 8(3):231-236.

23. Wang WW, Wu ZL, Dai ZL, Yang Y, Wang JJ, Wu G: Glycine metabolism in animals and humans: implications for nutrition and health. Amino Acids 2013, 45:463-477.

24. Kim SW, Wu G, Baker DH: Ideal protein and amino acid requirements by gestating and lactating sows. Pig News Inform 2005, 26:89N-99N.

25. Ball RO, Atkinson JL, Bayley HS: Proline as an essential amino acid for the young pig. Br J Nutr 1986, 55:659-668.

26. Elango $\mathrm{R}$, Ball RO, Pencharz PB: Recent advances in determining protein and amino acid requirements in humans. Br J Nutr 2012, 108(Suppl 2):S22-S30

27. Glista WA, Mitchell HH, Scott HM: The amino acid requirements of the chick. Poultry Sci 1951, 30:915.

28. Fisher $\mathrm{H}$, Scott HM: The essential amino acid requirements of chicks as related to their proportional occurrence in the fat-free carcass. Arch Biochem Biophys 1954, 51:517-519.

29. Price WA Jr, Taylor MW, Russell WC: The retention of essential amino acids by the growing chick. J Nutr 1953, 51:413-422.

30. Klain GJ, Scott HM, Johnson BC: The amino acid requirements of the growing chick fed a crystalline amino acid diet. Poultry Sci 1960, 39:39-44.

31. Baker DH, Sugahara M, Scott HM: The glycine-serine interrelationship in chick nutrition. Poultry Sci 1968, 47:1376-1377.

32. Graber G, Baker DH: The essential nature of glycine and proline for growing chickens. Poultry Sci 1973, 52:892-896.

33. Dean WF, Scott HM: The development of an amino acid reference diet for the early growth of chicks. Poultry Sci 1965, 44:803-808.

34. Huston RL, Scott HM: Effect of varying the composition of crystalline amino acid mixture on weight gain and pattern of free amino acids in chick tissue. Fed Proc 1968, 27:1204-1209.

35. Sasse CE, Baker DH: Modification of the Illinois reference standard amino acid mixture. Poultry Sci 1973, 52:1970-1972.

36. Baker DH, Han Y: Ideal amino acid profile for broiler chicks during the first three weeks posthatching. Poultry Sci 1994, 73:1441-1447.

37. NRC (National Research Council): Nutrient Requirements of Poultry. Washington, D.C: National Academy Press; 1994.

38. Baker DH: Ideal amino acid profiles for swine and poultry and their applications in feed formulation. BioKyowa Tech Rev No 1997, 9:1-24

39. Cole DJA: The amino acid requirements of pigs: the concept of an ideal protein. Pig News Info 1980, 1:201-205.

40. ARC (Agricultural Research Council): The Nutrient Requirements of Pigs: Technical review. Slough, U.K: Commonwealth Agricultural Bureaux; 1981.

41. NRC (National Research Council): Nutrient Requirements of Swine Washington, D.C: National Academy Press; 1988.

42. Wu G, Bazer FW, Burghardt RC, Johnson GA, Kim SW, Li XL, Satterfield MC, Spencer TE: Impacts of amino acid nutrition on pregnancy outcome in pigs: mechanisms and implications for swine production. J Anim Sci 2010, 88:E195-E204

43. Wu G, Ott TL, Knabe DA, Bazer FW: Amino acid composition of the fetal pig. J Nutr 1999, 129:1031-1038.
44. Davis TA, Nguyen HV, Garcia-Bravo R, Fiorotto ML, Jackson EM, Lewis DS, Lee DR, Reeds PJ: Amino acid composition of human milk is not unique. J Nutr 1994, 124:1126-1132.

45. Wang TC, Fuller MF: The optimum dietary amino acid patterns for growing pigs. 1. Experiments by amino acid deletion. Br J Nutr 1989, 62:77-89.

46. Chung TK, Baker DH: Ideal amino acid pattern for ten kilogram pigs. J Anim Sci 1992, 70:3102-3111.

47. Baker $\mathrm{DH}$ : Recent advances in use of the ideal protein concept for swine feed formulation. Asian-Aus J Anim Sci 2000, 13:294-301.

48. Wu G, Knabe DA, Kim SW: Arginine nutrition in neonatal pigs. J Nutr 2004, 134:2783S-2790S.

49. Mateo RD, Wu G, Bazer FW, Park JC, Shinzato I, Kim SW: Dietary L-arginine supplementation enhances the reproductive performance of gilts. $J$ Nutr 2007, 137:652-656

50. Mateo RD, Wu G, Moon HK, Carroll JA, Kim SW: Effects of dietary arginine supplementation during gestation and lactation on the performance of lactating primiparous sows and nursing piglets. J Anim Sci 2008, 86:827-835.

51. Yao K, Yin YL, Chu WY, Liu ZQ, Deng D, Li TJ, Huang RL, Zhang JS, Tan BE, Wang W, Wu G: Dietary arginine supplementation increases mTOR signaling activity in skeletal muscle of neonatal pigs. J Nutr 2008, 138:867-872

52. Tan BE, Li XG, Kong XF, Huang RL, Ruan Z, Yao K, Deng ZY, Xie MY, Shinzato I, Yin YL, Wu G: Dietary L-arginine supplementation enhances the immune status in early-weaned piglets. Amino Acids 2009, 37:323-331.

53. Kim SW, Wu G: Regulatory role for amino acids in mammary gland growth and milk synthesis. Amino Acids 2009, 37:89-95.

54. Wu G, Meier SA, Knabe DA: Dietary glutamine supplementation prevents jejunal atrophy in weaned pigs. J Nutr 1996, 126:2578-2584.

55. Wang JJ, Chen LX, Li P, Li XL, Zhou HJ, Wang FL, Li DF, Yin YL, Wu G: Gene expression is altered in piglet small intestine by weaning and dietary glutamine supplementation. J Nutr 2008, 138:1025-1032.

56. Haynes TE, Li P, Li XL, Shimotori K, Sato H, Flynn NE, Wang JJ, Knabe DA, Wu G: L-Glutamine or L-alanyl-L-glutamine prevents oxidant- or endotoxininduced death of neonatal enterocytes. Amino Acids 2009, 37:131-142.

57. Wu G, Bazer FW, Johnson GA, Knabe DA, Burghardt RC, Spencer TE, Li XL, Wang JJ: Important roles for L-glutamine in swine nutrition and production. J Anim Sci 2011, 89:2017-2030.

58. Manso HE, Filho HC, de Carvalho LE, Kutschenko M, Nogueira ET, Watford M: Glutamine and glutamate supplementation raise milk glutamine concentrations in lactating gilts. J Anim Sci Biotechnol 2012, 3(1):2.

59. Jiang $Z Y$, Sun $L H$, Lin YC, Ma XY, Zheng CT, Zhou GL, Chen F, Zou ST: Effects of dietary glycyl-glutamine on growth performance, small intestinal integrity, and immune responses of weaning piglets challenged with lipopolysaccharide. J Anim Sci 2009, 87:4050-4056.

60. Rezaei R, Knabe DA, Tekwe CD, Dahanayaka S, Ficken MD, Fielder SE, Eide SJ, Lovering SL, Wu G: Dietary supplementation with monosodium glutamate is safe and improves growth performance in postweaning pigs. Amino Acids 2013, 44:911-923.

61. Zhang J, Yin YL, Shu XG, Li TJ, Li FN, Tan BE, Wu ZL, Wu G: Oral administration of MSG increases expression of glutamate receptors and transporters in the gastrointestinal tract of young piglets. Amino Acids 2013, 45:1169-1177.

62. Xin W, Xugang S, Xie C, Li J, Hu J, Yin YL, Deng ZY: The acute and chronic effects of monosodium L-glutamate on serum iron and total ironbinding capacity in the jugular artery and vein of pigs. Biol Trace Elem Res 2013, 153:191-195.

63. Wu X, Zhang Y, Liu Z, Li TJ, Yin YL: Effects of oral supplementation with glutamate or combination of glutamate and $\mathrm{N}$-carbamylglutamate on intestinal mucosa morphology and epithelium cell proliferation in weanling piglets. J Anim Sci 2012, 90(Suppl 4):337-339.

64. Liu T, Peng J, Xiong Y, Zhou S, Cheng X: Effects of dietary glutamine and glutamate supplementation on small intestinal structure, active absorption and DNA, RNA concentrations in skeletal muscle tissue of weaned piglets during d 28 to 42 of age. Asian-Aust J Anim Sci 2002, 15:238-242.

65. Wu G, Bazer FW, Burghardt RC, Johnson GA, Kim SW, Knabe DA, Li P, Li XL, McKnight JR, Satterfield MC, Spencer TE: Proline and hydroxyproline metabolism: implications for animal and human nutrition. Amino Acids 2011, 40:1053-1063.

66. Brunton JA, Baldwin MP, Hanna RA, Bertolo RF: Proline supplementation to parenteral nutrition results in greater rates of protein synthesis in the muscle, skin, and small intestine in neonatal Yucatan miniature piglets. J Nutr 2012, 142:1004-1008. 
67. Brunton JA, Bertolo RF, Pencharz PB, Ball RO: Proline ameliorates arginine deficiency during enteral but not parenteral feeding in neonatal piglets. Am J Physiol 1999, 277:E223-E231.

68. Powell S, Bidner TD, Payne RL, Southern LL: Growth performance of 20- to 50- kilogram pigs fed low-crude-protein diets supplemented with histidine, cystine, glycine, glutamic acid, or arginine. J Anim Sci 2011, 89:3643-3650.

69. Fickler J, Roth FX, Kirchgessner M: Use of a chemically-defined amino acid diet in a $\mathrm{N}$-balance experiment with piglets. 1. Communication on the importance of nonessential amino acids for protein retention. J Anim Physiol Anim Nutr 1994, 72:207-214.

70. Kim SW, Baker DH, Easter RA: Dynamic ideal protein and limiting amino acids for lactating sows: the impact of amino acid mobilization. J Anim Sci 2001, 79:2356-2366.

71. Kim SW, Osaka I, Hurley WL, Easter RA: Mammary gland growth as influenced by litter size in lactating sows: impact on lysine requirement. J Anim Sci 1999, 77:3316-3321.

72. Andersen SM, Holen E, Aksnes A, Rønnestad I, Zerrahn JE, Espe M: Dietary arginine affects energy metabolism through polyamine turnover in juvenile Atlantic salmon (Salmo salar). Br J Nutr 2013, 110:1968-1977.

73. Pohlenz C, Buentello A, Criscitiello MF, Mwangi W, Smith R, Gatlin DM: Synergies between vaccination and dietary arginine and glutamine supplementation improve the immune response of channel catfish against Edwardsiella ictaluri. Fish Shellfish Immunol 2012, 33:543-551.

74. Zhang KK, Ai QH, Mai KS, Xu W, Liufu ZG, Zhang YJ, Peng M: Effects of dietary hydroxyproline on growth performance, body composition, hydroxyproline and collagen concentrations in tissues in relation to prolyl 4-hydroxylase alpha(I) gene expression of juvenile turbot, Scophthalmus maximus L. fed high plant protein diets. Aquaculture 2013, 404:77-84.

75. Fouad AM, El-Senousey HK, Yang XJ, Yao JH: Dietary L-arginine supplementation reduces abdominal fat content by modulating lipid metabolism in broiler chickens. Animal 2013, 7:1239-1245.

76. Wu LY, Fang YJ, Guo XY: Dietary L-arginine supplementation beneficially regulates body fat deposition of meat-type ducks. Br Poult Sci 2011, 52:221-226

77. Dai SF, Gao F, Xu XL, Zhang WH, Song SX, Zhou GH: Effects of dietary glutamine and gamma-aminobutyric acid on meat colour, $\mathrm{pH}$, composition, and water-holding characteristic in broilers under cyclic heat stress. Br Poult Sci 2012, 53:471-481.

78. Powell S, Bidner TD, Southern LL: Effects of glycine supplementation at varying levels of methionine and cystine on the growth performance of broilers fed reduced crude protein diets. Poult Sci 2011, 90:1023-1027.

79. Li P, Kim SW, Nakagawa K, Zhou HJ, Wu G: Dietary supplementation with L- glutamine and AminoGut ${ }^{\mathrm{TM}}$ enhances protein synthesis in skeletal muscle of growing broiler chickens. FASEB J 2010, 24:740.21.

80. Ren W, Yin YL, Liu G, Yu X, Li Y, Yang G, Li T, Wu G: Effect of dietary arginine supplementation on reproductive performance of mice with porcine circovirus type 2 infection. Amino Acids 2012, 42:2089-2094.

81. Ren WK, Zou LX, Li NZ, Wang Y, Peng YY, Ding JN, Cai LC, Yin YL, Wu G: Dietary arginine supplementation promotes immune responses to inactivated Pasteurella multocida vaccination in mice. Br J Nutr 2013, 109:867-872.

82. Ren WK, Liu SP, Chen S, Zhang FM, Li NZ, Yin J, Peng YY, Wu L, Liu G, Yin YL, Wu G: Dietary L-glutamine supplementation increases Pasteurella multocida burden and expression of major virulence factors in mice. Amino Acids 2013, 45:947-955.

83. Ren WK, Zou LX, Ruan Z, Li NZ, Wang Y, Peng Y, Liu G, Yin YL, Huang RL, Hou YQ, Wu G: Dietary L-proline supplementation confers immuno-stimulatory effects on inactivated Pasteurella multocida vaccine immunized mice. Amino Acids 2013, 45:555-561

84. Kim SW, Wu G, Zhao Y, Li P: Applications of ideal protein and selection of protein sources for sows and piglets. In Progress in Functional Amino Acids and Carbohydrates for Animal Production. (Proceedings of $4^{\text {th }}$ International Symposium on Animal Nutrition, Health and Feed Additive, July 4-5, 2009, Guangzhou, China. Edited by Yin YL, Liu G, Spencer TE. Changsha, Hunan, China: Institute of Subtropical Agriculture, Chinese Academy of Sciences; 2009:32-40.

85. Li P, Mai KS, Trushenski J, Wu G: New developments in fish amino acid nutrition: towards functional and environmentally oriented aquafeeds. Amino Acids 2009, 37:43-53.

86. Kim SW, Hurley WL, Wu G, Ji F: Ideal amino acid balance for sows during gestation and lactation. J Anim Sci 2009, 87:E123-E132.
87. Ruth MR, Field CJ: The immune modifying effects of amino acids on gut-associated lymphoid tissue. J Anim Sci Biotechnol 2013, 4(1):27.

88. Wu G: Functional amino acids in growth, reproduction and health. Adv Nutr 2010, 1:31-37.

89. Wu G: Functional amino acids in nutrition and health. Amino Acids 2013, 45:407-411.

90. Parsons CM: Amino acid digestibility in feedstuffs for poultry: Feedstuff evaluation and requirements. BioKyowa Tech Rev No 1991, 1:1-15.

91. Li XL, Rezaei R, Li P, Wu G: Composition of amino acids in feed ingredients for animal diets. Amino Acids 2011, 40:1159-1168.

92. Huang RL, Yin YL, Wu G, Zhang YG, Li TJ, Li LL, Li MX, Tang ZR, Zhang J, Wang $B$, He JH, Nie XZ: Effect of dietary oligochitosan supplementation on ileal digestibility of nutrients and performance in broilers. Poultry Sci 2005, 84:1383-1388

93. Traylor SL, Cromwell GL, Lindemann MD, Knabe DA: Effects of level of supplemental phytase on ileal digestibility of amino acids, calcium, and phosphorus in dehulled soybean meal for growing pigs. J Anim Sci 2001, 79:2634-2642

94. Dai ZL, Wu ZL, Jia SC, Wu G: Analysis of amino acid composition in proteins of animal tissues and foods as pre-column o-phthaldialdehyde derivatives by HPLC with fluorescence detection. J Chromatogr B 2014, doi:10.1016/j.jchromb.2014.03.025.

95. Wu G: Dietary requirements of "nutritionally nonessential amino acids" by mammals. Amino Acids Res (Japan) 2014, 7:67-76.

96. Rezaei R, Wang WW, Wu ZL, Dai ZL, Wang JJ, Wu G: Biochemical and physiological bases for utilization of dietary amino acids by young pigs. J Anim Sci Biotechnol 2013, 4:7.

97. Li XL, Bazer FW, Johnson GA, Burghardt RC, Frank JW, Dai ZL, Wang JJ, Wu ZL, Shinzato I, Wu G: Dietary supplementation with L-arginine between days 14 and 25 of gestation enhances embryonic development and survival in gilts. Amino Acids 2014, 46:375-384.

98. Lin G, Wang XQ, Wu G, Feng CP, Zhou HJ, Li DF, Wang JJ: Improving amino acid nutrition to prevent intrauterine growth restriction in mammals. Amino Acids 2014, 46:1605-1623.

99. Wang XQ, Frank JW, Little DR, Dunlap KA, Satterfiled MC, Burghardt RC, Hansen TR, Wu G, Bazer FW: Functional role of arginine during the periimplantation period of pregnancy. I. Consequences of loss of function of arginine transporter SLC7A1 mRNA in ovine conceptus trophectoderm. FASEB J 2014, doi:fj.13-248757.

100. Wang XQ, Ying W, Dunlap KA, Lin G, Satterfield MC, Burghardt RC, Wu G Bazer FW: Arginine decarboxylase and agmatinase: An alternative pathway for de novo biosynthesis of polyamines for development of mammalian conceptuses. Biol Reprod 2014, 90:84.

101. Wu G, Bazer FW, Dai ZL, Li DF, Wang JJ, Wu ZL: Amino acid nutrition in animals: protein synthesis and beyond. Annu Rev Anim Biosci 2014, 2:387-417.

102. Bauchart-Thevret C, Stoll B, Benight NM, Olutoye O, Lazar D, Burrin DG: Supplementing monosodium glutamate to partial enteral nutrition slows gastric emptying in preterm pigs. J Nutr 2013, 143:563-570.

103. Wang WW, Dai ZL, Wu ZL, Lin G, Jia SC, Hu SD, Dahanayaka S, Wu G: Glycine is a nutritionally essential amino acid for maximal growth of milk-fed young pigs. Amino Acids 2014, doi:10.1007/s00726-014-1758-3.

104. Cabrera RA, Usry JL, Arrellano C, Nogueira ET, Kutschenko M, Moeser AJ, Odle J: Effects of creep feeding and supplemental glutamine or glutamine plus glutamate (Aminogut) on pre- and post-weaning growth performance and intestinal health of piglets. J Anim Sci Biotechnol 2013, 4:29.

105. Pi D, Liu Y, Shi H, Li S, Odle J, Lin X, Zhu H, Chen F, Hou Y, Leng W: Dietary supplementation of aspartate enhances intestinal integrity and energy status in weanling piglets after lipopolysaccharide challenge. J Nutr Biochem 2014, 25:456-462

106. Bazer FW, Song GW, Kim JY, Dunlap KA, Satterfield MC, Johnson GA, Burghardt RC, Wu G: Uterine biology in sheep and pigs. J Anim SCi Biotechnol 2012, 3:23.

107. Brosnan JT, Brosnan ME: Glutamate: a truly functional amino acid. Amino Acids 2013, 45:413-418.

108. Dai ZL, Li XL, Xi PB, Zhang J, Wu G, Zhu WY: L-Glutamine regulates amino acid utilization by intestinal bacteria. Amino Acids 2013, 45:501-512.

109. Ren WK, Luo W, Wu MM, Liu G, Yu XL, Jun F, Li TJ, Yin YL, Wu G: Dietary L-glutamine supplementation improves pregnancy outcome in mice infected with type-2 porcine circovirus. Amino Acids 2013, 45:479-488. 
110. Satterfield MC, Dunlap KA, Keisler DH, Bazer FW, Wu G: Arginine nutrition and fetal brown adipose tissue development in diet-induced obese sheep. Amino Acids 2012, 43:1593-1603.

111. Kalhan SC, Hanson RW: Resurgence of serine: an often neglected but indispensable amino Acid. J Biol Chem 2012, 287:19786-19791.

112. Ko HM, Oh SH, Bang HS, Kang NI, Cho BH, Im SY, Lee HK: Glutamine protects mice from lethal endotoxic shock via a rapid induction of MAPK phosphatase-1. J Immunol 2009, 182:7957-7962.

113. Gupta MK, Uhm SJ, Lee SH, Lee HT: Role of nonessential amino acids on porcine embryos produced by parthenogenesis or somatic cell nuclear transfer. Mol Reprod Dev 2008, 75:588-597.

114. Satterfield MC, Dunlap KA, Keisler DH, Bazer FW, Wu G: Arginine nutrition and fetal brown adipose tissue development in nutrient-restricted sheep. Amino Acids 2013, 45:489-499.

115. Sawant OB, Ramadoss J, Hankins GD, Wu G, Washburn SE: Effects of L-glutamine supplementation on maternal and fetal hemodynamics in gestating ewes exposed to alcohol. Amino Acids 2014, doi:10.1007/s00726-014-1751-x.

doi:10.1186/2049-1891-5-34

Cite this article as: Wu: Dietary requirements of synthesizable amino acids by animals: a paradigm shift in protein nutrition. Journal of Animal Science and Biotechnology 2014 5:34.

\section{Submit your next manuscript to BioMed Central and take full advantage of:}

- Convenient online submission

- Thorough peer review

- No space constraints or color figure charges

- Immediate publication on acceptance

- Inclusion in PubMed, CAS, Scopus and Google Scholar

- Research which is freely available for redistribution 